Poročilo Report (1.25)

UDK UDC: $27-67$

DOI:10.34291/Edinost/76/Skafar

(C) 2021 Škafar CC BY 4.0

Vinko Škafar

\title{
Nekaj izbranih besedil \\ o novejših dogodkih ekumenskega in medverskega dialoga
}

\author{
A Collection of some Recent Texts on Ecumenical \\ and Interreligious Dialogue
}

Objavljamo nekaj izbranih besedil o novejših dogodkih ekumenskega in medverskega dialoga, ki so tukaj zbrana za slovenskega bralca, da bo lažje zaznaval delovanje Svetega Duha na ekumenskem in medverskem področju.

Kardinal Kurt Koch, predsednik Papeškega sveta za pospeševanje edinosti kristjanov, je za Radio Vatikan tehtno spregovoril o pomembnosti novega italijanskega prevoda Skupne izjave glede nauka o opravičenju leta 1999, kar je še posebej pomembno za odnos med Katoliško cerkvijo in Svetovno luteransko zvezo. V L'Osservatre Romano pa je Koch objavil članek z naslovom Hoditi skupaj po isti poti. Sinodalnost z ekumenskega vidika, ki se nanaša na 1700-letnico prvega ekumenskega koncila v zgodovini Cerkve, ki je potekal leta $325 \mathrm{v}$ Niceji in je skupen in velik dar Svetega Duha za vso Cerkev, Vzhodno in Zahodno.

Kurt Koch je ob sklepu molitve za edinost kristjanov 25. januarja 2021 v baziliki sv. Pavla zunaj obzidja med molitvijo ustaljenih večernic prebral homilijo, ki jo je pripravil papež Frančišek in v kateri je poudarek na trti, ki je Gospod, na katerega smo kristjani vcepljeni kot mladike. Preroško sporočilo je o ekološki krizi na Halki Summitu izrekel ekumenski patriarh Bartolomej, ki je poudaril, da je pandemija obupan klic narave k njenemu 
spoštovanju. Pretresljivo je poročilo Leona Pontecorva Cerkev ga je rešila pred nacisti, ki so ga redovnice kot judovskega otroka - med drugo svetovno vojno - rešile pred nacisti.

Papež Frančišek je 4. 2. 2021 na spletnem srečanju mednarodnega dne človeškega bratstva, ki se ga je udeležil tudi veliki imam Al Azharja, Ahmad Al Tayeb, poudaril, da je bratstvo novi mejnik človeštva. K medverskemu dialogu pa je papež 6. marca 2021 dodal nov zelo pomemben prispevek na obisku v Iraku v mestu Najaf, današnjem središču iraških šiitov, kjer se je srečal z velikim šiitskim ajatolom Sayyidom Alijem Al-Husaynijem Al-Sistanijem. Na medverskem srečanju v Uru in v Mosulu je papež molil pretresljivo molitev v duhu bratstva vseh ljudi.

\section{Kardinal Koch o novem prevodu Skupne izjave glede nauka o opravičenju}

Predsednik Papeškega sveta za pospeševanje enosti kristjanov Kurt Koch je v intervjuju za Radio Vatikan spregovoril o pomenu in pomembnosti novega italijanskega prevoda Skupne izjave glede nauka o opravičenju iz leta 1999. Dikasterij za pospeševanje edinosti kristjanov in Svetovna luteranska zveza sta ga predstavila 3. januarja 2021.

\section{Razdeljenost lahko postane del zgodovine sprave}

»Ne moremo izbrisati zgodovine razdeljenosti, vendar pa ta lahko postane del naše zgodovine sprave, «je poudaril kardinal Koch ter dejal, da »Skupna izjava glede nauka o opravičenju iz leta 1999 predstavlja pomembno fazo na poti katoliško-luteranske sprave. Vprašanje, ki je ključnega pomena za naše krščansko življenje - Kako se pride do zveličanja in kako se ostane v zveličanju? - je v 16. stoletju izzvalo ostre razprave, ki so vodile v razdeljenost Cerkve. Po stoletjih polemik glede veroizpovedi so mogli leta 1999 katoličani in luterani skupaj sporazumno, kljub različnosti, izpovedati: 'Ne na osnovi naših zaslug, ampak samo po milosti in v veri v Kristusovo zveličavno delo nas Bog sprejema in prejemamo Svetega Duha, ki prenavlja naša srca, nas nagiba, da izvršujemo dobra dela, in nas zanje usposablja.'" (Skupna izjava glede nauka o opravičenju, 15) 


\section{Pomen nove izdaje dokumenta}

V nadaljevanju pogovora je kardinal podrobneje razložil vsebino nove izdaje, ki vključuje tudi nekatera besedila, ki so bila tokrat prvič prevedena v italijanščino. Poudaril je, da je bila Skupna izjava glede nauka o opravičenju iz leta 1999 prvotno dvostranski dokument, sad dialoga med luterani in katoličani, zatem pa so ga sprejeli tudi metodisti, anglikanci in reformirane Cerkve. Leta 2019 so se predstavniki vseh teh skupnosti srečali na Univerzi Notre Dame v Severni Ameriki, kjer so izrazili svojo pripravljenost, da si bodo tudi v prihodnosti prizadevali za ekumenizem. Vsa besedila, povezana s tem, so objavljena tudi v novi izdaji z željo, da bi bilo to posebno pričevanje o ekumenski spravi tudi v italijanskem svetu, predvsem katoliškem, bolj poznano.

\section{Nov prevod, predstavljen 500 let po izobčenju Lutra}

Ekumenski uvod v izdajo z novim prevodom Skupne izjave glede nauka o opravičenju je poleg kardinala Kocha podpisal tudi generalni tajnik Svetovne luteranske zveze, Martin Junge. Dokument je bil objavljen 3. januarja letos. Takrat je namreč minilo 500 let, odkar je papež Leon X. izobčil Martina Lutra. To dejanje po besedah kardinala Kocha »še naprej predstavlja bolečo rano v zgodovini katoliško-luteranske razdeljenosti. Lutrova obsodba papeža kot 'antikrista' je bila prav tako razlog za medsebojno oddaljitev. Svetovna luteranska zveza in Papeški svet za pospeševanje enosti kristjanov sta pred izzivom, saj morata z ekumenskega vidika pojasniti zgodovinska, teološka in kanonska vprašanja, povezana z izobčenjem Martina Lutra.« Kardinal Koch je izrazil upanje, da bodo v bližnji prihodnosti lahko objavili "Skupno sporočilo«. S tega vidika je po njegovem mnenju pomembno, da je uvod v novo izdajo podpisal tudi Martin Junge, saj sta tako skupaj pokazala, da obe skupnosti še naprej želita odločno nadaljevati pot sprave pod vodstvom evangelija.

\section{s. Leonida Zamuda, Radio Vatikan}




\section{Hoditi skupaj po isti poti: pomembni obletnici naproti}

Ob začetku tedna za edinost kristjanov (18. 1. 2021) je vatikanski časopis L'Osservatore Romano objavil članek kardinala Kurta Kocha z naslovom Hoditi skupaj po isti poti. Sinodalnost z ekumenskega vidika, ki ga v nadaljevanju povzemamo.

Ves krščanski svet se približuje pomembni obletnici. Leta 2025 bomo obhajali 1700-letnico prvega ekumenskega koncila v zgodovini Cerkve, ki je potekal leta $325 \mathrm{v}$ Niceji. Ta pomembni dogodek je bil nedvomno zaznamovan tudi z mnogimi zgodovinskimi dejavniki. Med njimi je predvsem treba spomniti, da ga je sklical cesar, natančneje cesar Konstantin. To je mogoče razumeti le ob upoštevanju zgodovinskega ozadja oz. dejstva, da je v tedanjem obdobju v krščanskem svetu izbruhnila ostra razprava glede načina, kako bi bila lahko izpoved krščanske vere v Jezusa Kristusa, ki je Božji Sin, v skladu z vero, prav tako krščansko, v enega Boga. V tej razpravi je cesar prepoznal resno nevarnost za svoj načrt, da bi utrdil edinost cesarstva na temelju enosti krščanske vere. V razdeljenosti Cerkve, ki se je začela kazati, je videl predvsem politični problem, vendar pa je bil tudi dovolj daljnoviden, da je razumel, da enosti Cerkve ne bo mogoče doseči po politični, ampak le po verski poti. Da bi ponovno združil nasprotna stališča, je cesar Konstantin sklical prvi ekumenski koncil v mestu Niceja v Mali Aziji v bližini prestolnice Konstantinopel, ki jo je ustanovil on.

\section{Nicejska veroizpoved temelj skupne krščanske vere}

V tem zgodovinskem kontekstu je še bolj očitno, kako zelo pomemben je bil prvi ekumenski koncil. Zavrnil je model strogo filozofskega monoteizma, ki ga je širil aleksandrijski teolog Arij, ki je dejal, da je Kristus »Božji Sin«lahko le v nepravem pomenu. Nasproti temu modelu je koncil postavil izpoved vere v Jezusa Kristusa, Božjega Sina, »enega bistva z Očetom«. Nicejska veroizpoved je postala temelj skupne krščanske vere glede na to, da je nicejski koncil potekal v trenutku, ko krščanstvo še ni bilo razkosano zaradi številnih poznejših razdeljenosti. Koncilska veroizpoved še danes združuje vse krščanske Cerkve in cerkvene skupnosti in ima velik ekumenski pomen. Ekumenska ponovna vzpostavitev edinosti Cerkve namreč predpostavlja uskladitev glede bistvenih vsebin vere, pa ne le med današnjimi Cerkvami in cerkvenimi skupnostmi, ampak tudi 
uskladitev s Cerkvijo preteklosti in predvsem z njenim apostolskim izvorom. 1700. obletnica nicejskega koncila bo torej ugodna priložnost za to, da bi se spominjali tega koncila v ekumenskem občestvu ter na prenovljen način premišljevali o njegovi kristološki izpovedi vere.

\section{Sinodalnost kot ekumenski izziv}

Nicejski koncil ima velik ekumenski pomen še z drugega vidika. Pričuje namreč o načinu, kako se v Cerkvi razpravlja o spornih vprašanjih in se jih sinodalno razreši na koncilu. To nakazuje že sama beseda: izraz "sinoda» je sestavljen iz grških besed hodos (pot) in syn (z) ter izraža skupno hojo na poti. V krščanskem smislu beseda pomeni skupno pot oseb, ki verujejo v Jezusa Kristusa, ki se je razodel kot "pot«, in še natančneje kot »pot, resnica in življenje« (Jn 14,6). Krščanska vera se je torej prvotno imenovala "pot«, in kristjane, ki so sledili Kristusu, ki je Pot, so imenovali "privrženci Poti« (Apd 9,2).V tem smislu je Janez Krizostom razložil, da je bila »cerkev« ime, »ki kaže skupno pot", in da sta cerkev in sinoda »sinonima" (Explicatio in Ps, 149). Beseda »sinodalnost« je torej tako starodavna in temeljna kot beseda »cerkev«.

Nicejski koncil torej zaznamuje začetek - veljaven za vesoljno Cerkev sinodalnega načina, ki se uporablja pri procesu odločanja. Gre za drugo pomembno ugotovitev, ki je ključnega pomena z ekumenskega vidika, kot kažeta dva nedavna dokumenta: pred nekaj leti je komisija Vera in cerkvena ureditev pri Ekumenskem svetu Cerkva objavila študijo z naslovom Cerkev na poti skupne vizije, ki predlaga mulilateralen in ekumenski pogled na naravo, cilj in poslanstvo Cerkve. V tej študiji beremo naslednjo skupno ekleziološko izjavo z ekumenskega vidika: „Pod vodstvom Svetega Duha je vsa Cerkev sinodalna/koncilska na vseh ravneh cerkvenega življenja: krajevnega, pokrajinskega in vesoljnega. V taki sinodalnosti ali koncilskosti odseva skrivnost trinitarnega življenja Boga in strukture Cerkve izražajo to z namenom, da bi se uresničilo življenje skupnosti kot skupnost.«(Št. 53) Glede tega vidika je istega mnenja tudi Mednarodna teološka komisija v svojem dokumentu Sinodalnost $v$ življenju in poslanstvu Cerkve. V besedilu se z veseljem ugotavlja, da je ekumenski dialog napredoval do te mere, da je mogoče v sinodalnosti prepoznati »razodevajočo razsežnost narave Cerkve«, ta pa se steka v pojmovanje "Cerkve kot občestva (koinonia), ki se uresničuje v vsaki delni Cerkvi in v njenem 
razmerju do drugih Cerkva preko posebnih struktur in sinodalnih procesov« (št. 116).

\section{Poslušati Svetega Duha sinodalno}

V tem ekumenskem duhu je tudi papež Frančišek močno izrazil svojo naklonjenost do spodbujanja sinodalnih postopkov v Katoliški cerkvi. Prepričan je, da je odločno sledenje in poglobitev poti sinodalnosti "pot, ki jo Bog pričakuje od Cerkve tretjega tisočletja» (Govor ob 50-letnici ustanovitve škofovske sinode, 17. oktober 2015). Vendar pa svetega očeta ne skrbijo toliko strukture in ustanove kot duhovna razsežnost sinodalnosti, v kateri sta temeljnega pomena vloga Svetega Duha in skupno poslušanje Svetega Duha: »Poslušajmo, razpravljajmo v skupini, predvsem pa bodimo pozorni na to, kar nam ima Sveti Duh povedati.«(Ritorniamo a sognare, 97) Iz tega močnega duhovnega poudarka se razume tudi razlika med sinodalnostjo in demokratičnim parlamentarizmom, ki jo papež Frančišek vztrajno poudarja. Medtem ko demokratični proces služi predvsem za določanje večin, je sinodalnost duhovni dogodek, katerega namen je doseči trajno in prepričljivo enodušnost na poti razločevanja glede verskih prepričanj in doslednih načinov življenja posameznih kristjanov in skupnosti Cerkve. Sinoda torej »ni parlament, kjer se zato, da bi dosegli soglasje ali sporazum, zateče k pogajanju ali kompromisom, ampak je edina sinodalna metoda odpreti se Svetemu Duhu z apostolskim pogumom, evangeljsko ponižnostjo in zaupno molitvijo; da bo On tisti, ki nas bo vodil.« (Nagovor ob začetku zasedanja sinode o družini, 5. oktober 2015)

Iz pravkar rečenega lahko razumemo, da je za papeža Frančiška najprej treba poglobiti idejo sinodalnosti kot temeljne in bistvene strukture Katoliške cerkve: »Biti Cerkev je biti skupnost, ki hodi skupaj. Ni dovolj imeti sinodo, treba je biti sinod. Cerkev potrebuje resno notranjo podelitev: živi dialog med Pastirji ter med Pastirji in verniki." (Govor škofom Ukrajinske grkšokatoliške cerkve, 5. julij 2019) Iz tega nedvoumno izhaja tudi to, da sinodalnost ni nasprotna hierarhični strukturi Cerkve, ampak da sinodalnost in hierarhija potrebujeta in spodbujata druga drugo. Sinodalnost kot sestavna razsežnost Cerkve nam torej »daje najustreznejši razlagalni okvir za razumevanje hierarhičnega poslanstva« v smislu, da se »tisti, ki predstavljajo avtoriteto, imenujejo služabniki: glede na izvirni 
pomen besede so izmed vseh najmanjši« (Govor ob 50-letnici ustanovitve škofovske sinode, 17. oktober 2015). Za papeža Frančiška to velja tudi in predvsem za sam petrinski primat, ki more najti svoj najjasnejši izraz v sinodalni Cerkvi: »Papež ni sam, nad Cerkvijo, ampak je znotraj nje kot krščeni med krščenimi ter znotraj škofovskega zbora kot škof med škofi, istočasno pa - kot naslednik apostola Petra - poklican voditi Cerkev v Rimu, ki predseduje v ljubezni vsem Cerkvam."

Očitna je torej tudi ekumenska razsežnost sinodalnosti Cerkve z vidika papeža Frančiška. Za svetega očeta "pozoren pregled načina, kako sta v življenju Cerkve izražena načelo sinodalnosti in služenje tistega, ki predseduje», predstavlja pomemben prispevek k ekumenski spravi med krščanskimi Cerkvami (Nagovor med srečanjem z delegacijo carigrajskega ekumenskega patriarhata, 27. junij 2015). Teološka in pastoralna prizadevanja, da bi zgradili sinodalno Cerkev, imajo globok vpliv na ekumenizem, kakor poudarja papež Frančišek, s temeljnim načelom ekumenskega dialoga, ki ga sestavlja izmenjava darov, zahvaljujoč kateri se moremo učiti drug od drugega. Ta izmenjava zadeva predvsem sprejem tega, kar je Sveti Duh posejal v drugih Cerkvah »kot dar tudi za nas«. V tem smislu papež Frančišek opominja, da imamo katoličani v dialogu s pravoslavnimi brati priložnost, da se »naučimo kaj več o pomenu škofovske kolegialnosti in o izkušnji sinodalnosti« (Evangelii gaudium, št. 246). Glede na to, da to zadeva osrednjo temo katoliško-pravoslavnega dialoga, je treba podrobneje pojasniti ekumensko razsežnost sinodalnosti na podlagi tega pomembnega dialoga.

\section{Sinodalnost in primat $v$ katoliško-pravoslavnem dialogu}

V tem dialogu je bil storjen pomemben korak med plenarnim zasedanjem mednarodne mešane komisije v Ravenni leta 2007, kjer je bil potrjen dokument $\mathrm{z}$ naslovom Ekleziološke in kanonske posledice zakramentalne narave Cerkve. Cerkveno občestvo, koncilskost in oblast. V tem dokumentu se s teološkega vidika razjasnijo izrazi »koncilskost « in »oblast« ter »sinodalnost« in "primat«. Dalje je prikazano, da se sinodalnost in primat udejanjata na treh temeljnih ravneh življenja Cerkve, tj. na krajevni, ki zadeva delno Cerkev, na pokrajinski, ki zadeva različne delne Cerkve v bližini, ki so medsebojno povezane, ter na vesoljni ravni, ki zadeva Cerkev, razširjeno po vsem svetu, in ki vključuje vse delne Cerkve. V naslednjem koraku je poudarjeno, da sta sinodalnost in primat medsebojno odvisna 
na vseh ravneh življenja Cerkve, v smislu, da je potrebno primat vedno razumevati in uresničevati $\mathrm{v}$ okviru sinodalnosti in sinodalnost $\mathrm{v}$ okviru primata. To konkretno pomeni, da mora obstajati neki protos, kephale oz. glava, na vseh ravneh: na ravni delne Cerkve je škof protos (glava) svoje škofije glede na duhovnike in celotno Božje ljudstvo; na pokrajinski ravni je metropolit protos glede na škofe svoje metropolije; na vesoljni ravni je rimski škof protos glede na množico delnih Cerkva, medtem ko ima v pravoslavnih Cerkvah podobno vlogo carigrajski ekumenski patriarh. V zaključku dokument izraža prepričanje Komisije, ki zaupa, da so razmišljanja, predstavljena v zvezi s temo cerkvenega občestva, koncilskosti in oblasti Cerkve, "pozitiven in pomemben napredek v našem dialogu ter »trdna osnova za nadaljnjo razpravo o vprašanju primata na vesoljni ravni Cerkve« (št. 46).

Dejstvo, da sta Katoliška in Pravoslavna cerkev v dialogu lahko prvič skupaj izjavili, da je Cerkev strukturirana sinodalno na vseh ravneh, torej tudi na vesoljni ravni, in da potrebuje neko glavo (protos), je pomemben mejnik v katoliško-pravoslavnem dialogu. Da bi ta obetajoči korak vodil k trdni prihodnosti, bo treba odnos med sinodalnostjo in primatom dalje poglobiti znotraj ekumenskega dialoga. Ne gre za to, da bi dosegli kompromis glede najmanjšega skupnega imenovalca. Treba se bo pogovarjati glede močnih vidikov obeh cerkvenih skupnosti, kot je na sintetičen način opisala pravoslavno-katoliška delovna skupina Sveti Irenej v svoji študiji z naslovom V služenju skupnosti: „Cerkvi si morata prizadevati predvsem za to, da bi dosegli boljše ravnovesje med sinodalnostjo in primatom na vseh ravneh cerkvenega življenja z okrepitvijo sinodalnih struktur v Katoliški cerkvi in s tem, da Pravoslavna cerkev sprejme določene vrste primat znotraj svetovnega občestva Cerkva.«(Št. 17,7)

\section{Ekumenska sprava med sinodalnostjo in primatom}

Obe strani morata biti razpoložljivi za to, da bi se učili. Po eni strani mora Katoliška cerkev prepoznati, da v svojem življenju in svojih cerkvenih strukturah še ni razvila tiste stopnje sinodalnosti, ki bi bila teološko možna in potrebna, ter da bi verodostojna vez med hierarhičnim in sinodalno-skupnostnim načelom spodbujala napredek ekumenskega dialoga s pravoslavjem. Okrepitev sinodalnosti je nedvomno treba imeti 
za najpomembnejši doprinos, ki ga more Katoliška cerkev prispevati k ekumenskemu priznanju primata.

Predvsem je treba nadoknaditi neke vrste zamudo na ravni cerkvene pokrajine. Ta raven je v pravoslavnih Cerkvah dobro razvita, saj metropoliti še naprej opravljajo tisto pomembno nalogo, ki so jo imeli že v prvih stoletjih in glede katere so bile sprejete pomembne odločitve na prvem ekumenskem koncilu v Niceji leta 325 ter na četrtem ekumenskem koncilu v Kalcedonu leta 451. V zvezi s tem je treba spomniti tudi na znani 34. apostolski kanon, ki ga je priznavala prvotna Cerkev - tako na vzhodu kot na zahodu - in ki ureja odnose med delnimi Cerkvami določene pokrajine. Zanj je značilno tenkočutno ravnovesje med sinodalnostjo in primatom: "Škofje vsake cerkvene pokrajine morajo priznati tistega, ki je prvi med njimi, ga imeti za svojo glavo in ne smejo storiti ničesar pomembnega brez njegovega soglasja; vsak škof lahko opravlja samo to, kar zadeva njegovo škofijo in področja, ki so od nje odvisna. Vendar pa tisti, ki je prvi, ne more storiti ničesar brez soglasja vseh. Na ta način bo namreč prevladalo soglasje in Bog bo hvaljen po Gospodu v Svetem Duhu. Katoliška cerkev mora še veliko nadoknaditi na pokrajinski ravni cerkvenih provinc in cerkvenih pokrajin, posebnih koncilov in škofovskih konferenc, kot je dejal papež Frančišek: »Razmišljati moramo, da bi preko teh organizmov še bolj udejanjili vmesne stopnje kolegialnosti, morda tudi s tem, da bi vključili in posodobili nekatere vidike starodavne cerkvene ureditve." (Govor ob 50-letnici ustanovitve škofovske sinode, 17. oktober 2015)

S strani pravoslavnih Cerkva pa lahko pričakujemo, da bodo v ekumenskem dialogu prišle do spoznanja, da primat na vesoljni ravni ni le mogoč in teološko upravičen, ampak tudi potreben. Napetosti znotraj pravoslavja, ki so se posebej očitno pokazale na svetem in velikem sinodu na Kreti leta 2016, bi morale pomagati razumeti, da je treba službo enosti vzeti v ozir tudi na vesoljni ravni Cerkve. Ta seveda ne bi smela biti omejena zgolj na častni primat, ampak bi morala vključevati tudi pravne elemente. Tak primat na noben način ne bi bil v nasprotju z evharistično ekleziologijo, ampak bi bil z njo združljiv, kot pogosto spominja pravoslavni teolog in metropolit John D. Zizioulas. 


\section{Evharistična narava sinodalnosti in primata}

Mi katoličani imamo primat rimskega škofa za Gospodov dar njegovi Cerkvi in torej tudi za dar celotnemu krščanstvu na poti ponovnega odkrivanja edinosti in življenja v edinosti. Da bi jo lahko pokazali na verodostojen način, bi morali bolj poudariti dejstvo, da primat rimskega škofa ni zgolj nekakšen pravni dodatek in še manj neko zunanje dopolnilo k evharistični ekleziologiji, ampak prav na njej temelji. Cerkev, ki se ima za svetovno mrežo evharističnih skupnosti, potrebuje močno službo enosti tudi na vesoljni ravni. Primat rimskega škofa, kot je izrecno poudaril papež Benedikt XVI., je treba navsezadnje razumeti le izhajajoč iz evharistije, natančneje pa kot primat v ljubezni v evharističnem smislu; primat, ki v Cerkvi teži k enosti, ki bo sposobna udejanjiti evharistično občestvo in na verodostojen način preprečiti, da bi en oltar postavili nasproti drugemu.

Iz tega torej sledi, da imata tako primat kot sinodalnost globoko liturgičnoevharistično naravo. Dejstvo, da Cerkev kot sinoda živi predvsem tam, kjer se kristjani zbirajo k obhajanju evharistije, kaže, da je najgloblja narava sinodalne Cerkve evharistični zbor, kakor pravilno poudari Mednarodna teološka komisija: »Sinodalno pot Cerkve oblikuje in hrani evharistija." (Št. 47) Sinodalnost ima svoj izvor in svoj vrh v zavestnem in dejavnem evharističnem zboru in tako predstavlja eno izmed temeljnih duhovnih razsežnosti. To je še danes vidno v dejstvu, da se sinodalna zasedanja pa tudi koncili in zasedanja škofovskih sinod navadno začnejo z obhajanjem evharistije in s postavitvijo evangelija na središčno mesto, kot je bilo že predvideno v preteklosti, od koncilov v Toledu v 7. stoletju pa vse do Obrednika škofov iz leta 1984.

Sinodalno izročilo krščanstva vključuje bogato dediščino, ki bi jo morali ponovno oživiti. Pomenljivo znamenje je odločitev papeža Frančiška, da bo redno splošno zasedanje škofovske sinode, ki bo potekalo leta 2022, posvetil prav temi sinodalnosti: "Za sinodalno Cerkev: občestvo, soudeležba in poslanstvo«. Ta sinoda ne bo le pomemben dogodek v Katoliški cerkvi, ampak bo imela tudi pomembno ekumensko sporočilo, saj je sinodalnost vprašanje, ki spodbuja tudi ekumenizem, in sicer ga premika v globini. 


\section{Papež Frančišek o treh »kolobarjih edinosti«: zJezusom, kristjani in človeštvom}

V ponedeljek, 25. januarja 2021, je v baziliki sv. Pavla zunaj obzidja ob sklepu tedna molitve za edinost kristjanov potekala molitev večernic. Sveti oče, ki naj bi sicer vodil slovesnost, se je zaradi išiasa ni mogel udeležiti, zato je tokrat njegovo vlogo prevzel kardinal Kurt Koch, predsednik Papeškega sveta za pospeševanje edinosti kristjanov. Prebral je tudi homilijo, ki jo je pripravil papež Frančišek. V njej je poudaril, da smo na trto, ki je Gospod, kristjani vcepljeni kakor mladike. Za to, da bi ostajali v Njem, je bistvena molitev, poleg tega pa moramo živeti tudi enost $\mathrm{s}$ kristjani in $\mathrm{s}$ celotnim človeštvom.

\section{Na trto, ki je Gospod, smo vcepljeni kakor mladike}

"Ostanite v moji ljubezni." (Jn 15,9) Jezus povezuje to naročilo s prispodobo trte in mladike, zadnjo, ki nam jo podarja v evangelijih. Gospod sam je trta, »resnična« trta (v. 1), in se ne izneveri pričakovanjem, ampak ostaja zvest v ljubezni in vedno drži besedo kljub našim grehom in našim razdeljenostim. Na to trto, ki je On, smo vsi krščeni vcepljeni kakor mladike: to pomeni, da lahko rastemo in obrodimo sad, samo če smo združeni z Jezusom. Ta večer gledamo to nujno potrebno enost, ki ima več ravni. Ko pomislimo na trto, si lahko predstavljamo enost, ki jo sestavljajo trije koncentrični kolobarji kakor pri deblu.

\section{Enost in trije koncentrični kolobarji: ostati v Jezusu ...}

Prvi kolobar, najbolj notranji, je ostati v Jezusu. Od tod izhaja pot vsakogar k enosti. V današnji stvarnosti, ki je hitra in kompleksna, je lahko izgubiti nit, saj nas vleče na tisoče strani. Mnogi se čutijo notranje razdeljene, nesposobne najti trdno točko, stanoviten red v spremenljivih življenjskih okoliščinah. Jezus nam kaže skrivnost trdnosti $\mathrm{v}$ tem, da ostajamo v Njem. V odlomku, ki smo ga slišali, to misel ponovi kar sedemkrat (prim. v. 4-7.9-10). On namreč ve, da »brez njega ne moremo ničesar storiti« (prim. v. 6). Pokazal nam je tudi, kaj naj storimo, s tem ko nam je dal zgled: vsak dan se je umaknil na samotne kraje, da bi molil. Molitev potrebujemo kakor vodo za življenje. Osebna molitev, biti z Jezusom, adoracija, je bistvena za ostajanje v Njem. Je pot za to, da bi v Gospodovo srce položili 
vse tisto, kar napolnjuje naše srce, upanja in strahove, radosti in bolečine. Predvsem pa osredotočeni na Jezusa v molitvi izkusimo njegovo ljubezen. In naše bivanje iz nje zajema življenje kakor mladika, ki prejme limfo od debla. To je prva enost, naša osebna integriteta, delo milosti, ki jo prejemamo, ko ostajamo v Jezusu.

\section{Drugi kolobar: edinost s kristjani}

Drugi kolobar je edinost s kristjani. Smo mladike iste trte, smo vezne posode: dobro in zlo, ki ga vsakdo stori, se zgrinja na druge. V duhovnem življenju poleg tega velja neke vrste "zakon dinamike«: kolikor ostajamo v Bogu, se približamo drugim, in kolikor se približamo drugim, ostajamo v Bogu. To pomeni, da če molimo Boga v duhu in resnici, od tod izhaja tudi potreba, da ljubimo druge; po drugi strani pa, »če se ljubimo med seboj, Bog ostaja v nas" (1 Jn 4,12). Ni mogoče, da molitev ne bi vodila k ljubezni, sicer gre za površen ritualizem. Ni namreč mogoče srečati Jezusa brez njegovega Telesa, ki je sestavljeno iz mnogih udov, iz toliko, kolikor je krščenih. Če je naše češčenje pristno, bomo rasli v ljubezni do vseh tistih, ki sledijo Jezusu, ne glede na krščansko občestvo, ki mu pripadajo, kajti tudi če niso »naši«, so njegovi.

\section{Oče odstrani in očiščuje}

Kljub temu pa ugotavljamo, da ljubiti brate ni lahko, saj se takoj pojavijo njihove napake in pomanjkljivosti ter se $\mathrm{v}$ spomin vračajo rane preteklosti. Pri tem nam prihaja na pomoč poseg Očeta, ki kot izkušen vinogradnik (prim. Jn 15,1) dobro ve, kaj je treba storiti: „Vsako mladiko na meni, ki ne rodi sadu, odstrani; in vsako, ki rodi sad, očiščuj, da rodi še več sadu." (Jn 15,2) Oče odstrani in očiščuje. Zakaj? Ker se moramo zato, da bi ljubili, znebiti tistega, kar nas vodi s poti in zaradi česar se sklanjamo sami vase ter zato ne moremo obroditi sadu. Prosimo torej Očeta, naj odseka od nas predsodke o drugih in posvetne navezanosti, ki preprečujejo polno enost z vsemi njegovimi otroki. Tako prečiščeni v ljubezni bomo znali dati na stran zemeljske ovire in prepreke iz preteklosti, ki nas danes odvračajo od evangelija. 


\section{Tretji kolobar edinosti: celotno človeštvo}

Tretji kolobar edinosti, najširši, je celotno človeštvo. V tem okviru lahko razmišljamo o delovanju Svetega Duha. Na trti, ki je Kristus, je On limfa, ki dosega vse dele. Vendar pa Duh veje, kjer hoče, in povsod želi pripeljati $\mathrm{k}$ enosti. On nas vodi, da ljubimo ne le tistih, ki nas imajo radi in mislijo tako kot mi, ampak vse, kakor nas je naučil Jezus. Usposablja nas za to, da odpuščamo sovražnikom in odpuščamo krivice, ki smo jih doživeli. Spodbuja nas, da bi bili dejavni in ustvarjalni v ljubezni. Spominja nas, da bližnji ni le tisti, ki ima iste vrednote in ideje kot mi, ampak da smo poklicani, da bi postali bližnji vsem, dobri Samarijani ranjenega, ubogega in trpečega človeštva - danes zelo trpečega - ki leži po cestah sveta in ki ga Bog želi s sočutjem ponovno dvigniti. Sveti Duh, pobudnik milosti, naj nam pomaga živeti $\mathrm{v}$ zastonjskosti, ljubiti tudi tiste, ki nam ljubezni ne vračajo, saj evangelij prinaša sad v čisti in nesebični ljubezni. Drevo se po sadu spozna: po zastonjski ljubezni se spozna, če pripadamo Jezusovi trti.

\section{Sveti Duh nas uči konkretnosti ljubezni}

Sveti Duh nas tako uči konkretnosti ljubezni do vseh bratov in sester, s katerimi delimo isto človeškost, tisto človeškost, ki jo je Kristus neločljivo združil s seboj ter nam dejal, da ga bomo vedno našli v najbolj ubogih in pomoči potrebnih (prim. Mt 25,31-45). Če jim bomo služili skupaj, bomo ponovno odkrili, da smo bratje, ter bomo rasli v enosti. Sveti Duh, ki prenavlja obličje zemlje, nas prav tako spodbuja, naj skrbimo za skupni dom, naj pogumno izbiramo način, kako živimo in trošimo, saj je nasprotje od »obroditi sad«»izkoriščati« ter je sramotno zapravljati dragocene vire, ki jih mnogi nimajo.

\section{Zahvala vsem, ki so in bodo molili za edinost kristjanov}

Isti Duh, stvaritelj ekumenske poti, nas je ta večer privedel, da bi skupaj molili. In medtem ko izkušamo edinost, ki se rojeva, ko se obračamo na Boga z enim samim glasom, se želim zahvaliti vsem tistim, ki so v tem tednu molili in bodo še naprej molili za edinost kristjanov. S svojimi bratskimi pozdravi se obračam na predstavnike Cerkva in cerkvenih skupnosti, ki so se tukaj zbrali: na mlade pravoslavne in vzhodne pravoslavne, ki študirajo v Rimu s pomočjo Sveta za pospeševanje edinosti med kristjani; 
na profesorje in študente Ekumenskega inštituta Bossey, ki bi morali priti v Rim kakor v preteklih letih, vendar zaradi pandemije to ni bilo mogoče in nas spremljajo preko medijev.

\section{Ostanimo povezani v Kristusu}

Dragi bratje in sestre, ostanimo povezani v Kristusu: Sveti Duh, ki je izlit v naša srca, naj nam da čutiti, da smo Očetovi otroci, bratje in sestre med nami, bratje in sestre v edini človeški družini. Presveta Trojica, občestvo ljubezni, naj nam da rasti v edinosti.

Prevedla s. Leonida Zamuda, Radio Vatikan

\section{Patriarh Bartolomej: Pandemija je obupan klic narave $k$ njenemu spoštovanju}

Od 26. do 28. januarja 2021 je potekal Halki Summit, ki je v ospredje postavil temo, povezano $\mathrm{z}$ aktualnim stanjem na svetu: »Covid-19 in podnebne spremembe: živeti skupaj in se učiti od pandemije«. Kriza covida-19 ni maščevanje s strani Boga, ampak spodbuda k bolj spoštljivemu odnosu do okolja, je zatrdil ekumenski patriarh Bartolomej, sicer tudi pobudnik dogodka.

Četrti Halki Summit je vrh o okoljstveni odgovornosti, ki nosi ime po grškem otoku Halki, kjer se je običajno tudi odvijal. Letos je program obsegal vrsto spletnih seminarjev, ki so sledili izbrani temi »Covid-19 in podnebne spremembe: živeti skupaj in se učiti od pandemije«. Vrh je odprl ekumenski patriarh Bartolomej I., sicer pa je v razpravah sodelovala vrsta teologov, znanstvenikov in okoljevarstvenikov.

\section{Radikalno spremeniti odnos do sveta}

V navzočnosti številnih strokovnjakov je carigrajski ekumenski patriarh pozval k spremenjenemu pristopu k ekološki krizi. Problem pandemije je povezal z vprašanjem okolja in njenimi posledicami za življenje planeta. Kot je poudaril, je vrh na Halkiju vedno bil zaznamovan $z$ dialogom in sodelovanjem. In ravno ti pomembni vrednoti sta zelo potrebni v tem 
trenutku, tako zelo zaznamovanem s koronavirusom. »Prepričani smo, da vsako realno upanje po preoblikovanju podnebnih sprememb zahteva radikalno spremembo načina, $s$ katerim dojemamo in obravnavamo svet, « je poudaril Bartolomej ter dodal, da je del problema naše zavračanje, da bi nekaj žrtvovali za dobro drugih in zemlje.

\section{Uničevanje naravnega okolja ni napredek}

Ravno covid-19 nam je dal "neprecenljivo lekcijo o pomembnosti poslušanja in učenja od drugih" ter »razkril moč in vrednost ljubezni in solidarnosti«. Pandemija nas je spomnila, da je svet večji od naših skrbi in individualnih ambicij, večji od naše cerkve in skupnosti vernikov in večji od naših političnih moči in narodnih interesov, je zatrdil patriarh. Manjša onesnaženost okolja v mesecih zaprtja držav je pokazala, da "ni mogoč resnični napredek, če ta temelji na uničevanju naravnega okolja«.

\section{Poziv k večjemu spoštovanju narave}

Patriarh Bartolomej se je dotaknil tudi odnosa med vzrokom in učinkom ter izpostavil "neprestano in pretirano vmešavanje človeštva v naravo«, kot primere pa navedel ilegalno trgovino z divjimi živalmi, razgozdovanje, urbanizacijo, intenzivno kmetijstvo. Opozoril je tudi na "naglo širjenje nalezljivih bolezni in virusov z živali na žival in tudi na človekaw. Po patriarhovih besedah ne gre za naključje, da se "porast bolezni, ki jih prenašajo divje živali, pojavlja skupaj z naraščanjem človeškega poseganja $\mathrm{v}$ naravni svet in naglim spreminjanjem podnebja». Pandemija »ni maščevalno dejanje s strani Boga, ampak je obupan klic k pristopu, ki je mnogo bolj spoštljiv do narave s strani vseh nas,« je še zatrdil Bartolomej.

\section{Andreja Červek, Radio Vatikan}

\section{Leone Pontecorvo. Cerkev ga je rešila pred nacisti}

V času nacističnega preganjanja je imel Leone Pontecorvo osem let. Skupaj z mlajšim bratom Brunom se je skrival v samostanu sester oblatinj Svetega Srca Jezusovega v Rimu. Ob 32. dnevu za poglobitev in razvoj dialoga med 
katoličani in judi, ki je potekal v nedeljo, 17. januarja 2021, je za Vatican News spregovoril o takratnih dogodkih.

»Izkušnja, ki je ne bom nikoli pozabil, ki me je v življenju zaznamovala in mi okrepila judovsko identiteto, «je povedal Leone Pontecorvo, danes star 85 let. Osem mesecev je preživel v samostanu sester oblatinj v Rimu in se tako rešil pred nacisti.

\section{Ponarejeni dokumenti}

Bilo je oktobra 1943 in imel je osem let. Z mlajšim bratom Brunom, ki je bil star štiri leta, so ga sestre sprejele v ustanovo za fante. Njunemu očetu je uspelo dobiti ponarejene osebne dokumente neke družine, ki je bila ubita med bombardiranjem v Cassinu. Dobila sta priimek Buoncristiani.

\section{Nogomet in izmenjavanje svetih podobic}

Samo redovna predstojnica in upraviteljica šole sta vedeli, kdo sta v resnici Leone in Bruno. Nihče drug. In o tem sta zvesto molčali. »Bili sta izjemni. Bila sva kakor vsi drugi otroci, " pove Pontecorvo. Hitro sta se prilagodila strogim pravilom samostana: zbujanje ob zori, umivanje z mrzlo vodo, učenje, molitev, a tudi veliko prizanesljivosti in prostega časa. Leone je postal Cino Buoncristiani in začel organizirati nogometni turnir znotraj samostanskih zidov. Tudi bratec se ni nikoli dolgočasil ter je postal navdušen zbiralec - ne sličic z nogometaši, ampak podobic s svetniki, ki jih je bilo $\mathrm{v}$ predalih sester na pretek.

\section{Molitve v latinščini in služenje pri oltarju}

Kljub zaskrbljenosti, kaj se je zgodilo staršem, ki so jih prijatelji kristjani skrivali v zazidani sobi stanovanja, je šolsko življenje zamotilo oba otroka. »Po nekaj tednih sem se navadil na vsa pravila samostanskega življenja," se spominja Pontecorvo. »Od molitev v latinščini do pomoči pri maši.» Leone, takrat Cino, je v šoli veljal za najboljšega: »Upošteval sem naročilo svojih staršev in hotel na najboljši način odigrati tisto vlogo, tako da sem poslal najboljši med ministranti. Ob dveh pomembnih priložnostih, za božič in veliko noč, sem bil med več kot petdesetimi katoliškimi otroci v šoli izbran, da pri maši služim ob škofu. Pismo, ki sem ga pisal 
svojim staršem za veliko noč -« se spominja - »je bilo pismo stoodstotno katoliškega otroka. A nikoli se na naju ni pritiskalo, da bi se spreobrnila v krščanstvo."

\section{Strah}

Leone Pontecorvo še vedno hrani veliko spominov na tisti čas. Med najljubšimi mu je spomin na »najlepši obraz, kar sem jih kdaj videl«, obraz ene od sester, ki je zanj ljubeče skrbela, ko je zaradi vročine obležal v postelji. Spominja pa se tudi trenutkov, polnih strahu. Nekega dne je na stopnišču samostana naletel na neko gospo, ki je za roke držala njegovega brata in mu govorila: "Jaz vem, kdo si. Ti nisi Bruno Buoncristiani, ti si Bruno Pontecorvo! Jaz sem kot ti! «eone se je takoj vmešal in osvobodil jokajočega Bruna. »Morda je tudi ona bila judinja. Pobegnila je in nikoli več je nisem videl,« doda.

\section{Pomoč, ki jo je Cerkev nudila judom}

Bruno in Leone sta po osvoboditvi, 4. junija 1944, samostan sester oblatinj zapustila s solzami v očeh. Leonovo srce je še vedno polno hvaležnosti tistim sestram. Nikoli več jih ni videl. »V polemikah sem se vedno postavil na stran Pija XII., papeža, ki je odprl vrata vseh samostanov. Pripravljen je bil pomagati judom. Samo v Rimu jih je bilo zaščitenih pet tisoč.« Pontecorvo, čeprav prizna, da z določenega zgodovinskega vidika ne razume papeževe odločitve za delovanje v tišini, pove: »Pij XII. si zasluži največjo zahvalo sveta. Njegova gostoljubnost do judov znotraj cerkva in samostanov je bila izjemna."

\section{Andreja Červek, Radio Vatikan}

\section{Papež ob dnevu človeškega bratstva: Bratstvo kot novi mejnik človeštva}

Danes, 4. 2. 2021, poteka prvi mednarodni dan človeškega bratstva. Papež Frančišek ga je obeležil s sodelovanjem na spletnem srečanju, ki se ga je udeležil tudi veliki imam Al Azharja, Ahmad Al Tayeb. Mednarodni dan človeškega bratstva je ustanovila Generalna skupščina Združenih narodov ter 
za datum postavila 4. februar, dan, ko sta pred dvema letoma papež in veliki imam v Abu Dabiju podpisala Dokument o človeškem bratstvu. Med današnjim spletnim srečanjem je bila podeljena tudi nagrada za človeško bratstvo Zayed 2021. Prejela sta jo Latifa Ibn Ziaten in Antonio Guterres.

\section{Papež: Ali bratje ali pa bomo vse izgubili}

Papež Frančišek je svoj prispevek k današnjemu srečanju dal po videosporočilu, v katerem je bratstvo opredelil kot poslušanje, spoštovanje in iskreno sprejemanje. Poudaril je, da ne smemo izgubljati časa, kajti smo na mejniku človeštva: ali bratstvo ali pa se bomo med seboj uničili.

»Sestre in bratje. To je beseda: sestre in bratje, «je začel svoje videosporočilo sveti oče in se najprej zahvalil velikemu imamu Ahmadu Al Tayebu, ki ga je imenoval »brat, prijatelj, tovariš v izzivih in nevarnostih boja za bratstvo«. Zahvalil se mu je "za tovarištvo na poti« in za pripravo Dokumenta o človeškem bratstvu, ki sta ga skupaj podpisala pred dvema letoma: »Vaše pričevanje mi je zelo pomagalo, saj je bilo pogumno pričevanje. Vem, da naloga ni bila lahka. Z Vami sva jo lahko opravila skupaj in si vzajemno pomagala. Najlepša med vsemi stvarmi pa je, da se je tista prva želja po bratstvu utrdila kot resnično bratstvo. Hvala, brat, hvala."

Frančišek je zahvalo izrazil tudi šejku Mohamedu bin Zayedu, ki je organizator današnjega spletnega srečanja in se ga je prav tako udeležil. Poudaril je njegov trud za nadaljevanje te poti: »Verjel je v projekt. Verjel je nam.»

Besede zahvale pa je sveti oče namenil še sodniku Mohamedu Mahmoudu Abdelu Salamu, ki je generalni tajnik Visokega odbora za človeško bratstvo. Imenoval ga je "prijatelj, delavec, poln idej«.

»Hvala vsem, ki so stavili na bratstvo, kajti bratstvo je danes novi mejnik človeštva. Ali bomo bratje ali pa se bomo med seboj uničili, «je poudaril papež Frančišek in opozoril, da danes ni časa za brezbrižnost: »Ne moremo si oprati rok z distanco, z zanemarjanjem, z nezanimanjem. Ali smo bratje ali pa - dovolite mi - se bo vse podrlo. To je mejnik. Mejnik, na katerem moramo graditi. Je izziv našega stoletja, je izziv našega časa. Bratstvo pomeni iztegnjeno roko, bratstvo pomeni spoštovanje. Bratstvo pomeni 
poslušati z odprtim srcem. Bratstvo pomeni trdnost v lastnih prepričanjih. Kajti ni resničnega bratstva, če se pogajamo o lastnih prepričanjih.»

Po Frančiškovih besedah smo namreč »bratje, rojeni iz istega Očeta«: »Z različnimi kulturami in tradicijami, a vsi bratje. In v spoštovanju svoje kulture različnih tradicij, svojih različnih državnih pripadnosti je treba graditi to bratstvo. Ne pa se o njem pogajati.

Je trenutek poslušanja. Je trenutek iskrenega sprejemanja. Je trenutek gotovosti, da je svet brez bratov svet sovražnikov. Hočem poudariti: ne moremo reči ali bratje ali nebratje. Povejmo, kot je: ali bratje ali sovražniki. Kajti zanemarjanje je zelo prefinjena oblika sovraštva. Ni treba vojne, da bi postali sovražniki. Zadostuje zanemarjanje. Dovolj je te tehnike - postala je namreč tehnika - te drže, da gledamo na drugo stran, da ne skrbimo za drugega, kakor da ne bi obstajal.«Pri tem se je papež ponovno zahvalil velikemu imamu za pomoč in pričevanje, za »to pot, ki sva jo opravila skupaj«.

Papež Frančišek se je v nadaljevanju videosporočila obrnil še na oba dobitnika nagrade Zayed 2021, Latifo Ibn Ziaten in Antonia Guterresa. Generalnemu sekretarju Združenih narodov Guterresu se je zahvalil za "ves trud za mir«: »Mir, ki se lahko doseže samo z bratskim srcem.»

Nagovoril je še Latifo Ibn Ziaten: »Draga sestra, tvoje zadnje besede 'vsi smo bratje' niso bile izrečene zaradi vljudnosti. So prepričanje. Gre za prepričanje, ki je oblikovano v bolečini, v tvojih ranah. Svoje življenje si namenila za nasmeh, svoje življenje si namenila, da ne bi čutila zamere; in preko bolečine ob izgubi sina - samo mati ve, kaj pomeni izgubiti otroka - preko te bolečine imaš pogum reči 'vsi smo bratje' ter sejati besede ljubezni. Hvala za tvoje pričevanje. In hvala, da si mati svojemu otroku, mnogim dečkom in deklicam, da si danes mati temu človeštvu, ki te posluša in se od tebe uči: ali pot bratstva, ali bratje - ali pa bomo vse izgubili."

\section{Andreja Červek, Radio Vatikan}




\section{Papežv Iraku, 5.-8. marec 2021}

\subsection{Govor papeža Frančiška med srečanjem s predstavniki iraške oblasti, civilne družbe in diplomatskega zbora (Bagdad, predsedniška palača, 5. marec 2021)}

Gospod predsednik, člani vlade in diplomatskega zbora, spoštovani oblastniki, predstavniki civilne družbe, gospe in gospodje!

Hvaležen sem za priložnost, da lahko opravim ta apostolski obisk, zelo dolgo pričakovan in želen, $v$ Republiki Irak; da lahko pridem $\mathrm{v}$ to deželo, zibelko civilizacije, ki je po očaku Abrahamu in številnih prerokih tesno povezana z zgodovino zveličanja in z velikimi verskimi tradicijami judovstva, krščanstva in islama. Izražam svojo hvaležnost predsedniku Salehu za povabilo in za prijazne besede dobrodošlice, ki mi jih je namenil v imenu oblasti in svojega ljubljenega naroda. Enako pozdravljam člane diplomatskega zbora in predstavnike civilne družbe.

Pozdravljam z naklonjenostjo škofe in duhovnike, redovnike in redovnice in vse vernike Katoliške cerkve. Prihajam kot romar, da bi jih opogumil pri njihovem pričevanju vere, upanja in ljubezni sredi iraške družbe. Pozdravljam tudi člane drugih Cerkva in krščanskih cerkvenih skupnosti, pripadnike islama in predstavnike preostalih verskih tradicij. Bog naj nam da, da bomo hodili skupaj, kakor bratje in sestre, $v$ »močnem prepričanju, da različna učenja verstev vabijo, naj ostanemo zasidrani v vrednotah miru, [...] vzajemnega poznavanja, človeškega bratstva in skupnega sobivanja« (Dokument o človeškem bratstvu, Abu Dabi, 4. februar 2019).

Moj obisk se odvija v času, ko se ves svet poskuša rešiti iz krize pandemije covida-19, ki ni le prizadel zdravja mnogih oseb, ampak je prav tako povzročil poslabšanje socialnih in ekonomskih pogojev, že zaznamovanih $s$ krhkostjo in nestabilnostjo. Ta kriza zahteva skupne napore s strani vsakega, da bi opravili mnogo potrebnih korakov, med katerimi je pravična distribucija cepiva za vse. A to ni dovolj: ta kriza je predvsem poziv, da "ponovno premislimo svoje življenjske sloge [...], smisel našega bivanja« 
(Fratelli tutti, 33). Gre za to, da iz tega časa preizkušnje pridemo boljši, kot smo bili prej; da gradimo prihodnost bolj na tem, kar nas povezuje, kot na tistem, kar nas ločuje.

V prejšnjih desetletjih je Irak trpel zaradi katastrof vojn, nadloge terorizma in sektaških konfliktov, pogosto osnovanih na fundamentalizmu, ki ne more sprejeti mirnega sobivanja različnih etničnih in verskih skupin, idej in različnih kultur. Vse to je povzročilo smrt, uničenje, razvaline, ki so še vedno vidne, in to ne samo na materialni ravni: škoda je še globlja, če pomislimo na rane v srcih mnogih oseb in skupnosti, ki bodo potrebovale leta in leta za ozdravitev. In tu, med mnogimi, ki so trpeli, ne morem, da ne bi spomnil na jazide, nedolžne žrtve nespametnega in nečloveškega barbarstva, preganjane in ubite zaradi svoje verske pripadnosti, katerih sama identiteta in preživetje sta bila v nevarnosti. Zatorej: samo če nam uspe gledati se med seboj, s svojimi razlikami, kakor člani iste človeške družine, bomo lahko sprožili dejanski proces rekonstrukcije in prihodnjim generacijam zapustili boljši svet, pravičnejši in bolj človeški. V zvezi s tem je verska, kulturna in etnična raznolikost, ki že tisočletja zaznamuje iraško družbo, dragocen vir, iz katerega se mora zajemati, in ne ovira, ki jo je treba odstraniti. Danes je Irak poklican pokazati vsem, predvsem na Bližnjem vzhodu, da razlike ne smejo biti vzrok konfliktov, temveč jih moramo povezati v harmonijo v civilnem življenju.

Bratsko sožitje potrebuje potrpežljiv in iskren dialog, zaščiten s pravičnostjo in spoštovanjem prava. Ne gre za lahko nalogo: zahteva napor in prizadevanje vseh, da bi se rivalstvo in nasprotovanja presegli, ter pogovor, ki se začne pri najgloblji identiteti, ki jo imamo, to je, da smo otroci enega Boga in Stvarnika (Nostra aetate, 5). Na osnovi tega načela se Sveti sedež, tako v Iraku kot drugod, ne naveliča pozivati kompetentnih oblasti, naj vsem verskim skupnostim zagotovijo priznanje, spoštovanje, pravice in zaščito. Cenim ves napor, ki se je že vložil v tem smislu, ter pridružujem svoj glas glasu moških in žensk dobre volje, naj nadaljujejo delo v korist države.

Družba, ki nosi odtis bratske edinosti, je družba, v kateri člani med seboj živijo v solidarnosti. »Solidarnost nam pomaga videti drugega [...] kot svojega bližnjega, tovariša na poti« (Poslanica za 54. svetovni dan miru, 1. januar 2021). Gre za krepost, ki nas vodi v konkretna dejanja oskrbe 
in služenja s posebno pozornostjo do najranljivejših in pomoči potrebnih. Mislim na tiste, ki so zaradi nasilja, preganjanja in terorizma izgubili svojce in drage osebe, dom in osnovne dobrine. A mislim tudi na vse ljudi, ki se vsak dan borijo v iskanju varnosti in sredstev za življenje, medtem ko naraščata brezposelnost in revščina. „Čutiti se odgovorne za šibkost drugih" (Fratelli tutti, 115) bi moralo navdihniti vsak napor za ustvarjanje konkretnih priložnosti tako na ekonomski ravni kot na področju vzgoje in skrbi za stvarstvo, naš skupni dom. Po krizi ni dovolj obnavljati, to je treba opraviti dobro: na način, da lahko imajo vsi dostojno življenje. Iz krize ne pridemo enaki kot prej: pridemo ali boljši ali slabši.

Kot odgovorni politiki in diplomati ste poklicani pospeševati ta duh bratske solidarnosti. Nujno je zoperstaviti se nadlogi korupcije, zlorabam moči in ilegalnosti, a to ni zadosti. Hkrati je treba zgraditi pravičnost, večati iskrenost in transparentnost ter okrepiti ustrezne institucije. Na ta način lahko raste stabilnost in se razvija zdrava politika, zmožna vsem, predvsem pa mladim - tako številnim v tej državi - ponuditi upanje na boljšo prihodnost.

Gospod predsednik, spoštovane oblasti, dragi prijatelji! Prihajam kot spokornik, ki nebesa in brate prosi odpuščanje za mnoga uničenja in krutosti, in prihajam kot romar miru v imenu Kristusa, vladarja miru. Koliko smo v teh letih molili za mir v Iraku! Sv. Janez Pavel II. ni varčeval z iniciativami, predvsem pa je za to daroval molitve in trpljenje. In Bog posluša, Bog vedno posluša! Na nas je, da poslušamo Njega, hodimo po njegovih poteh. Naj umolkne orožje! Naj se omeji njegovo širjenje, tukaj in vsepovsod! Naj se nehajo delni interesi, tisti zunanji interesi, ki jih ne zanima lokalno prebivalstvo. Naj se da glas graditeljem, ustvarjalcem miru! Malim, revnim, preprostim ljudem, ki hočejo živeti, delati, moliti v miru. Dovolj nasilja, dovolj ekstremizmov, frakcij, nestrpnosti! Naj se dodeli prostor vsem državljanom, ki želijo skupaj graditi to državo, v dialogu, poštenem in iskrenem, konstruktivnem soočenju; tistemu, ki si prizadeva za spravo in je za skupno dobro pripravljen postaviti lastne interese na stran. V teh letih je Irak poskušal postaviti temelje za demokratično družbo. V tem smislu je nepogrešljivo zagotoviti udeležbo vsem političnim, družbenim in verskim skupinam ter zagotoviti temeljne pravice vsem državljanom. Naj nihče ni obravnavan kot drugorazredni državljan. Spodbujam doslej opravljene korake na tej poti in upam, da se okrepita vedrina in sloga. 
Tudi mednarodna skupnost mora opraviti odločilno vlogo pri pospeševanju miru v tej deželi in na celotnem Bližnjem vzhodu. Kot smo to videli med dolgim konfliktom v bližnji Siriji - od njegovega začetka v teh dneh mineva že deset let! - se izzivi vedno bolj tičejo celotne človeške družine. Zahtevajo sodelovanje na globalni ravni, da bi se pristopilo tudi k ekonomskim neenakostim in regionalnim napetostim, ki postavljajo v nevarnost stabilnost teh ozemelj. Zahvaljujem se državam in mednarodnim organizacijam, ki si v Iraku prizadevajo za rekonstrukcijo in za zagotovilo pomoči beguncem, notranjim preseljencem in tistim, ki se trudijo vrniti se na svoje domove, ko v državi zagotavljajo hrano, vodo, bivališča, zdravstvene in higienske storitve pa tudi programe, namenjene spravi in izgradnji miru. Pri tem ne morem mimo mnogih agencij, med katerimi so različne katoliške, ki že leta z veliko zavzetostjo pomagajo civilnemu prebivalstvu. Priti naproti osnovnim potrebam mnogih bratov in sester je dejanje dejavne ljubezni in pravičnosti ter prispeva k trajnemu miru. Upam, da države iraškemu narodu ne bodo umaknile iztegnjene roke prijateljstva in konstruktivnega zavzemanja, ampak bodo nadaljevale delo v duhu skupne odgovornosti z lokalnimi oblastmi ter brez vsiljevanja političnih in ideoloških interesov.

Verstvo mora po svoji naravi biti v službi miru in bratstva. Ime Boga ne more biti uporabljeno za »upravičevanje ubijanj, pregona, terorizma in zatiranja« (Dokument o človeškem bratstvu, Abu Dabi, 4. februar 2019). Nasprotno pa nas Bog, ki je ustvaril človeška bitja enaka v dostojanstvu in pravicah, kliče, naj širimo ljubezen, dobrohotnost, slogo. Tudi v Iraku želi Katoliška cerkev biti prijateljica vseh in preko dialoga na konstruktiven način sodelovati z drugimi verstvi za mir. Starodavna navzočnost kristjanov v tej deželi in njihov prispevek k življenju dežele predstavljata bogato dediščino, ki želi nadaljevati služenje vsem. Soudeležba kristjanov v javnem življenju kot državljanov, ki v polnosti uživajo pravice, svobodo in odgovornost, bo pričevala, da zdrav verski, etnični in kulturni pluralizem lahko prispeva k blaginji in harmoniji države.

Dragi prijatelji, še enkrat želim izraziti iskreno hvaležnost za vse, kar ste naredili in še naprej delate, da bi na koncu zgradili družbo, v katero so vtkane bratska edinost, solidarnost in sloga. Vaša služba za skupno dobro je plemenito delo. Vsemogočnega prosim, naj vas podpira pri vaših odgovornostih in vas vodi po poti upanja, pravičnosti in resnice. Nad vsakega med 
vami, na vaše družine in vaše drage ter na ves iraški narod kličem obilje božjega blagoslova. Hvala!

\section{Prevedla Andreja Červek, Radio Vatikan}

\subsection{Medversko srečanju v Uru (na Kaldejskem)}

Drugi dan apostolskega potovanja v Irak je papež Frančišek začel s srečanjem z velikim ajatolom Sayyidom Alijem Al-Husaynijem Al-Sistanijem v mestu Najaf, ki je danes versko središče iraških šiitov. Zatem pa se je podal na planoto Ur, kjer se danes nahajajo ostanki enega najstarejših in najpomembnejših sumerskih mest, ki velja za rojstni kraj Abrahama - očaka, ki povezuje jude, kristjane in muslimane. In ravno tukaj se je 6. marca 2021 kmalu po 9. uri začelo medversko srečanje. Brala sta se odlomka iz Prve Mojzesove knjige in Korana, oba povezana z Abrahamom, sledila pa so pričevanja: dveh mladih - muslimana in kristjana, vernice verske skupnosti sabea mandea in pripadnika muslimanske skupnosti.

Papež Frančišek je v svojem govoru izpostavil pot miru, na kateri moramo ostati skupaj. Mir ne zahteva ne zmagovalcev ne premaganih, ampak brate in sestre, ki kljub nerazumevanju in preteklim ranam hodijo od konflikta k edinosti, je poudaril ter spodbudil h konkretnim korakom. Nujno je namreč vzgajati za bratstvo. Samo skupaj z drugimi se lahko ozdravijo rane preteklosti. Izstopiti moramo iz sebe, kajti potrebujemo drug drugega.

\section{Govor papeža Frančiška na medreligijskem srečanju}

Ta blagoslovljeni kraj nas vrača k začetkom, k izvirom Božjega delovanja, k rojstvu naših verstev. Tu, kjer je živel naš oče Abraham, se nam zdi, da smo se vrnili domov. Tukaj je slišal Božji klic, od tod se je podal na potovanje, ki je spremenilo zgodovino. Mi smo sad tiste hoje in tistega potovanja. Bog je rekel Abrahamu, naj se ozre proti nebu in prešteje zvezde (1 Mz 15,5). V tistih zvezdah je videl obljubo svojega potomstva, videl je nas. In danes mi, judje, kristjani in muslimani, skupaj z brati in sestrami drugih verstev častimo očeta Abrahama, ko storimo kakor on: gledamo v nebo in hodimo po zemlji. 
Gledamo v nebo. Ko po tisočletjih zremo isto nebo, se pojavijo iste zvezde. Razsvetljujejo najmračnejše noči, kajti sijejo skupaj. Nebo nam tako daje sporočilo edinosti: Najvišji nad nami nas vabi, naj se nikoli ne ločimo od brata, ki je ob nas. Božji Onkraj nas usmeri k bratu kot drugemu. A če želimo varovati bratstvo, ne moremo izgubiti izpred oči Neba. Mi, Abrahamovi potomci in predstavniki različnih verstev, čutimo, da imamo predvsem tole vlogo: pomagati našim bratom in sestram, da pogled in molitev dvignejo v Nebo. Vsi ga potrebujemo, kajti sami sebi nismo dovolj. Človek ni vsemogočen, sam ne more ničesar. In če izključi Boga, konča v čaščenju zemeljskih stvari. A dobrine sveta, zaradi katerih mnogi pozabijo na Boga in druge, niso razlog našega potovanja na zemlji. Dvignimo oči v Nebo, da jih bomo tako dvignili s pritlehnosti nečimrnosti; služimo Bogu, da bomo izstopili iz suženjstva jaza, kajti Bog nas spodbuja ljubiti. To je resnična vernost: častiti Boga in ljubiti bližnjega. V današnjem svetu, ki pogosto pozabi Najvišjega ali pa o njem ponuja popačeno podobo, so verniki poklicani pričevati njegovo dobroto, pokazati njegovo očetovstvo s svojim bratstvom.

S tega izvornega kraja vere, iz dežele našega očeta Abrahama, trdimo, da je Bog usmiljen in da je najbolj bogoskrunska žalitev oskrunjenje njegovega imena s sovraštvom do brata. Sovražnost, ekstremizem in nasilje ne nastanejo iz verskega duha: so izdajstva verstva. Mi verniki ne moremo molčati, kadar terorizem zlorablja verstvo. Nasprotno, na nas je, da jasno razkrojimo napačna razumevanja. Ne dovolimo, da bi luč Neba bila prekrita z oblaki sovraštva! Nad to deželo so se zgostili temni oblaki terorizma, vojne in nasilja. Trpele so vse etnične in verske skupnosti. Želel bi posebej spomniti na skupnost jazidov, ki je objokavala smrt mnogih moških in videla na tisoče žensk, mladih in otrok, ki so bili ugrabljeni in prodani kot sužnji ter podvrženi fizičnemu nasilju in prisilnemu spreobrnjenju. Danes molimo za vse, ki so doživeli to trpljenje, ki so še vedno pogrešani in ugrabljeni, da bi se kmalu vrnili na svoje domove. In molimo, da bi bili vsepovsod spoštovani in priznani svoboda vesti in verska svoboda: gre za temeljni pravici, kajti človeka naredita svobodnega, da zre Nebo, za katero je bil ustvarjen.

Ko je terorizem vdrl na sever te ljube dežele, je okrutno uničil del njene čudovite verske dediščine, med drugim cerkve, samostane in kraje čaščenja različnih skupnosti. A tudi v tistem temnem trenutku so sijale zvezde. 
Mislim na mlade prostovoljce muslimane iz Mosula, ki so pomagali ponovno urediti cerkve in samostane, $s$ tem pa so gradili bratska prijateljstva na razvalinah sovraštva, in na kristjane in muslimane, ki danes skupaj obnavljajo mošeje in cerkve. Profesor Ali Thajeel nam je tudi povedal o vrnitvi romarjev v to mesto. Pomembno je romati na svete kraje: to je najlepše znamenje hrepenenja po Nebu na zemlji. Zato je ključno in nujno ljubiti in varovati svete kraje s spominom na našega očeta Abrahama, ki je na različnih mestih proti nebu dvignil oltarje Gospodu (prim. 1 Mz 12,7.8; 13,18; $22,9)$. Veliki očak naj nam pomaga, da bomo iz svetih krajev naredili oaze miru in srečanja za vse! On je zaradi svoje zvestobe Bogu blagoslov za vse rodove (prim. 1 Mz 12,3); naj bo naša navzočnost danes tukaj, po njegovih sledeh, znamenje blagoslova in upanja za Irak, za Bližnji vzhod in za ves svet. Nebo se ni utrudilo nad zemljo: Bog ljubi vsak narod, vsako njegovo hčer in vsakega njegovega sina! Nikoli se ne utrudimo gledati neba, gledati te zvezde, iste, ki jih je ob svojem času gledal naš oče Abraham.

Hodimo po zemlji. Oči, uprte v nebo, Abrahama niso odvrnile, temveč so ga spodbudile, da je hodil po zemlji, se podal na potovanje, ki se bo po njegovih potomcih dotaknilo vseh stoletij in ozemelj. A vse se začne tukaj, z Gospodom, ki ga je »izpeljal iz Ura« (prim. 1 Mz 15,7). Njegova je torej bila pot izhoda, ki je vsebovala žrtve: moral je zapustiti zemljo, hišo in sorodstvo. A s tem ko se je odpovedal svoji družini, je postal oče družine narodov. Tudi nam se zgodi kaj podobnega: na poti smo poklicani zapustiti tiste vezi in navezanosti, ki nas zapirajo v naše skupine, preprečujejo nam, da bi sprejeli neskončno Božjo ljubezen in v drugih videli brate. Ja, treba nam je izstopiti iz nas samih, kajti potrebujemo drug drugega. Pandemija nam je dala razumeti, da "se nihče ne reši sam« (Okrožnica Fratelli tutti, 54). Pa vendar se vedno vrača skušnjava, da bi se distancirali od drugih. A »tisti 'Reši se, kdor se more' se bo naglo spremenil v 'Vsi proti vsem', in to bo slabše od pandemije« (36). V viharjih, skozi katere hodimo, nas ne bo rešila osamitev, ne bo nas rešilo zatekanje k okrepitvi oboroževanja in dvigovanju zidov, nasprotno, to nas bo vedno bolj oddaljilo in razjezilo. Ne bo nas rešila idolatrija denarja, ki zapira vase in povzroča prepade neenakosti, v katere se človeštvo pogreza. Ne bo nas rešilo potrošništvo, ki anestezira misli in paralizira srce.

Pot, ki nam jo kaže Nebo, je neka druga, je pot miru. Ta zahteva, da, predvsem v viharju, ostanemo skupaj na isti strani. Sramotno je, 
da nekdo - medtem ko smo vsi preizkušani s pandemično krizo in predvsem tukaj, kjer so konflikti povzročili veliko nesreče - lakomno misli na svoje zadeve. Ne bo miru brez podelitve in sprejemanja, brez pravičnosti, ki zagotavlja enakost in napredovanje za vse, začenši pri najšibkejših. Ne bo miru, dokler bodo drugi drugi in mi mi. Ne bo miru, dokler bodo zavezništva proti nekomu, kajti zavezništva nekaterih proti drugim samo povečujejo ločevanje. Mir ne terja ne zmagovalcev ne premaganih, ampak brate in sestre, ki kljub nerazumevanju in preteklim ranam hodijo od konflikta k edinosti. To prosimo v molitvi za ves Bližnji vzhod, posebej mislim na bližnjo, mučeno Sirijo.

Očak Abraham, ki nas je danes zbral v edinosti, je bil prerok Najvišjega. Starodavna prerokba pravi, da bodo narodi »svoje meče prekovali v lemeže in svoje sulice v srpe« (Iz 2,4). Ta prerokba se ni uresničila, nasprotno, meči in sulice so postali rakete in bombe. Kje se torej lahko začne pot miru? Pri tem, da se odpovemo sovražnikom. Kdor ima pogum gledati zvezde, kdor veruje v Boga, nima sovražnikov, s katerimi bi se boril. Ima samo enega sovražnika, ki stoji pred vrati srca in trka, da bi vstopil: to je sovraštvo. Medtem ko nekateri poskušajo imeti več sovražnikov kot prijateljev, medtem ko mnogi iščejo lastno korist na škodo drugih, pa tisti, ki gleda zveze obljub in sledi Božjim potem, ne more biti proti nekomu, ampak $z a$ vse. Ne more upravičevati nobene oblike zapovedovanja, zatiranja in zanemarjanja, ne more delovati na agresiven način.

Dragi prijatelji, je vse to mogoče? Oče Abraham, on, ki je znal upati proti vsakemu upanju (prim. Rim 4,18), nas opogumlja. Skozi zgodovino smo pogosto zasledovali preveč zemeljske cilje in vsak je hodil po svoje, a z Božjo pomočjo lahko to spremenimo na boljše. Na nas je, na današnjem človeštvu, in predvsem na nas, vernikih vsake veroizpovedi, da orodja sovraštva preoblikujemo v orodja miru. Na nas je, da odločno pozivamo odgovorne v državah, naj naraščajoče bohotenje orožja odstopi mesto razdeljevanju hrane za vse. Na nas je, da umolknejo vzajemne obtožbe in se dá glas zatiranim in odvrženim na planetu: preveč jih je prikrajšanih za kruh, zdravila, izobrazbo, pravice in dostojanstvo! Na nas je, da na svetlo postavimo sumljive manevre, ki se vrtijo okoli denarja, in na vso moč zahtevamo, naj denar ne konča vedno in samo za ohranjanje nebrzdanega udobja nekaterih. Na nas je varovati skupen dom pred našimi zavzetimi plenilci. Na nas je spominjati svet, da je človeško življenje zato, ker je, in ne 
za to, kar ima, in da so življenja še nerojenih, ostarelih, migrantov, moških in žensk vsake barve kože in nacionalnosti vedno sveta in so vredna enako kot življenja vseh! Na nas je imeti pogum in dvigniti oči ter gledati zvezde, zvezde, ki jih je videl naš oče Abraham, zvezde obljube.

Abrahamova pot je bila blagoslov miru. A ni bilo lahko: moral se je soočiti z boji in nepričakovanim. Tudi mi imamo pred sabo naključno pot, a kakor veliki očak moramo narediti konkretne korake, poromati pred odkritje obličja drugega, podeliti spomine, poglede in tišine, zgodbe in izkušnje. Ganilo me je pričevanje Dawooda in Hasana, kristjana in muslimana, ki si nista pustila vzeti poguma pred razlikami in sta skupaj študirala in delala. Skupaj sta zgradila prihodnost in se prepoznala kot brata. Tudi mi, da bi šli naprej, moramo skupaj narediti nekaj dobrega in konkretnega. To je pot, predvsem za mlade, ki ne smejo videti svojih sanj zlomljenih zaradi preteklih konfliktov! Nujno je, da se vzgajajo za bratstvo, za gledanje zvezd. To je resnična in dejanska nujnost; to bo najučinkovitejše cepivo za jutrišnji mir. Kajti vi, dragi mladi, ste naša sedanjost in naša prihodnost!

Samo z drugimi se lahko ozdravijo rane preteklosti. Gospa Rafah nam je povedala o junaškem zgledu Najyja iz verske skupnosti sabea mandaea, ki je izgubil življenje med reševanjem družine svojega soseda muslimana. Koliko ljudi je tukaj, v tišini in brez zanimanja sveta, začelo poti bratstva! Rafah nam je prav tako povedala o neizrekljivem trpljenju zaradi vojne, ki je mnoge prisilila, da so zapustili domove in domovino ter odšli iskat prihodnost za svoje otroke. Hvala, Rafah, da si z nami podelila trdno odločnost, da ostaneš tu, v deželi svojih očetov. Naj tisti, ki jim to ni uspelo in so morali bežati, najdejo dobrohoten sprejem, vreden ranljivih in ranjenih oseb.

Ravno preko gostoljubnosti, ki je značilna za to deželo, je Abraham prejel obisk Boga in že skoraj nepričakovani dar sina (prim. 1 Mz 18,1-10). Mi, bratje in sestre različnih verstev, smo se srečali tukaj, doma, in od tod si želimo skupaj prizadevati, da bi uresničili sanje Boga: da bi človeška družina postala gostoljubna in sprejemajoča do vseh svojih otrok; da bi gledala $\mathrm{v}$ isto nebo in hodila $\mathrm{v}$ miru po tej zemlji. 


\section{Papež Frančišek: Molitev Abrahamovih otrok na medreligijskem srečanju v Uru}

Tebi, vsemogočni Bog, naš Stvarnik, ki imaš rad človeško družino in vse, kar so tvoje roke ustvarile, se mi, Abrahamovi sinovi in hčere, ki pripadamo judovstvu, krščanstvu in islamu, skupaj z drugimi verniki ter osebami dobre volje zahvaljujemo, da si nam podaril kot skupnega očeta v veri Abrahama, znamenitega sinu te plemenite in drage dežele.

Zahvaljujemo se ti za njegov zgled moža vere, ki te je popolnoma ubogal, zapustil svojo družino, svoje pleme in svojo domovino ter odšel proti deželi, ki je ni poznal.

Še posebej se ti zahvaljujemo za njegovo junaško vero, ki jo je pokazal s pripravljenostjo žrtvovati svojega sina, da bi bil pokoren tvojemu ukazu. Vemo, da je bila to zelo težka preizkušnja, iz katere pa je izšel kot zmagovalec, ker je brez zadržkov zaupal Tebi, ki si usmiljen in ki vedno odpiraš nove možnosti za ponovni začetek.

Zahvaljujemo se ti, ker si z blagoslovom našega očeta Abrahama iz njega napravil blagoslov za vsa ljudstva.

Prosimo te, Bog našega očeta Abrahama, da nam podeliš močno vero, dejavno z dobrimi deli, torej vero, ki bo odprla naša srca Tebi in vsem našim bratom in sestram, ter neukrotljivo upanje, ki bo sposobno povsod opaziti tvoje obljube.

Vsakega od nas napravi za pričevalca tvoje ljubeče skrbi do vseh, še posebej do beguncev in brezdomcev, do vdov in sirot, do revežev in bolnikov.

Naša srca odpri za medsebojno odpuščanje in napravi nas za orodje sprave in graditelje bolj pravične in bratske družbe.

Sprejmi v svoje bivališče miru in luči vse pokojne, še posebej žrtve nasilja in vojne.

Pomagaj civilnim oblastem pri iskanju in najdevanju ugrabljenih oseb ter pri zaščiti še zlasti žena in otrok. 
Pomagaj nam skrbeti za planet, skupni dom, ki si ga v svoji dobroti in velikodušnosti dal vsem nam.

Podpiraj naše roke pri obnovi te dežele in daj nam potrebno moč, da bomo pomagali tistim, ki so morali zapustiti svoje domove in zemljo, da se varno vrnejo in z dostojanstvom začnejo svoje novo, vedro in uspevajoče življenje. Amen.

\section{Prevedla Andreja Červek, Radio Vatikan}

\subsection{Papežv Mosulu: Kličemo po tvojem odpuščanju ter prosimo za milost spreobrnjenja}

Papež Frančišek je tretji dan, 7. marca 2021, svoje 33. apostolsko potovanje začel z letom iz Bagdada v Erbil. Na letališču v Erbilu je bil najprej sprejem predsednika avtonomne dežele iraškega Kurdistana ter verskih in civilnih oblasti te dežele. Sledilo je srečanje s predsednikom in predsednikom vlade avtonomne dežele iraškega Kurdistana v predsedniški loži VIP letališča Erbil. Potem pa je sveti oče s helikopterjem odletel v Mosul, kjer je bila zadušna molitev za žrtve vojne na Hosh al-Bieaa (Trgu cerkve) v Mosulu.

\section{Papežev pozdrav med zadušno molitvijo v Mosulu}

Dragi bratje in sestre, dragi prijatelji!

Zahvaljujem se nadškofu Najeebu Michaeelu za njegove besede dobrodošlice, še posebej pa sem hvaležen očetu Raidu Kallu in gospodu Gutaybiju Aaghu za njuni pretresljivi pričevanji.

Najlepša hvala, oče Raid. Pripovedovali ste nam o prisilnem izseljevanju številnih krščanskih družin iz njihovih domov. Tragično zmanjšanje Kristusovih učencev tukaj in na vsem Srednjem vzhodu je ogromna škoda ne samo za neposredno vpletene osebe in skupnosti, ampak za družbo samo, ki so jo zapustili. Dejansko je z različnostjo tako bogato kulturno in versko tkivo oslabljeno zaradi enega, kateregakoli svojega člana, pa naj bo še tako majhen. Kakor na kateri od vaših umetniških preprog lahko ena izvlečena nit poškoduje celoto. Vi, oče, ste govorili tudi o bratski izkušnji, ki jo živite z muslimani, potem ko ste se vrnili v Mosul. Našli ste gostoljubnost, spoštovanje in sodelovanje. Hvala vam, oče, da ste podelili 
ta znamenja Svetega Duha, ki daje cveteti v puščavi, in da ste nam nakazali, kako je mogoče upati v spravo in v novo življenje.

Gospod Aagha, spomnili ste nas, da je resnična identiteta tega mesta harmonično sobivanje oseb različnega izvora in kulture. Zaradi tega z velikim zadovoljstvom sprejemam vaše povabilo krščanski skupnosti, naj se vrne v Mosul ter ponovno prevzame sebi lastno vitalno vlogo v procesu ozdravitve in prenove.

Danes dvigamo svoje glasove v molitvi k Vsemogočnemu Bogu za vse žrtve vojne in oboroženih spopadov. Tukaj v Mosulu so tragične posledice vojne in sovražnosti več kot očitne. Kako kruto je, da je to deželo, zibelko civilizacije, prizadela tako nečloveška nevihta, ki je za sabo pustila uničene starodavne verske objekte in na tisoče in tisoče oseb, tako muslimanov kot kristjanov - jazidov, ki jih je terorizem kruto uničil - ki so bile prisilno izseljene ali pa ubite!

Danes ne glede na vse ponovno potrjujemo svoje prepričanje, da je bratstvo močnejše od bratomora, da je upanje močnejše od smrti ter da je mir močnejši od vojne. To prepričanje govori z bolj zgovornim glasom kakor sovraštvo in nasilje ter ne bo nikoli zadušeno v preliti krvi tistih, ki pačijo ime Boga tako, da hodijo po poteh uničevanja.

\section{Papeževe uvodne besede $v$ molitev}

Preden bomo molili za vse žrtve vojne v tem mestu Mosul, v Iraku in na celotnem Srednjem vzhodu, bi rad z vami podelil te misli:

- Če je Bog Bog življenja - in to je - nam ni dovoljeno ubijati bratov v njegovem imenu.

- Če je Bog Bog miru - in to je - nam ni dovoljeno iti se vojno v njegovem imenu.

- Če je Bog Bog ljubezni - in to je - nam ni dovoljeno sovražiti bratov.

Zdaj skupaj molimo za vse žrtve vojne, da jim Vsemogočni Bog podeli večno življenje in brezkončni mir ter jih sprejme v svoj ljubeči objem. 
Molimo pa tudi za vse nas, da bi ne glede na versko pripadnost lahko živeli v sožitju in miru z zavestjo, da smo v Božjih očeh vsi bratje in sestre.

\section{Papeževa molitev}

Najvišji Bog, Gospod časa in zgodovine. Ti si iz ljubezni ustvaril svet in ne nehaš izlivati na svoje stvaritve svojega blagoslova. Ti ne glede na ocean trpljenja in smrti, ne glede na skušnjave nasilja, krivičnosti in nepravičnega zaslužka spremljaš s svojo nežno Očetovsko ljubeznijo svoje sinove in svoje hčere.

Toda mi, ljudje, smo, nehvaležni za tvoje darove in raztreseni zaradi preveč posvetne zaskrbljenosti in ambicije, pogosto pozabili tvoje načrte miru in sožitja. Zaprli smo se vase ter v svoje sebične interese in smo brezbrižni do Tebe in drugih zagradili vrata pred mirom. Tako se je ponovilo to, kar je prerok Jona slišal reči o Ninivah: zlobnost ljudi se je dvignila vse do nebes (prim. Jon 1,2). Proti nebu nismo dvigovali čistih rok (prim. 1 Tm 2,8), ampak se je z zemlje ponovno dvigal krik nedolžne krvi (prim. $1 \mathrm{Mz}$ $4,10)$. Prebivalci Niniv so, kot stoji v Jonovi pripovedi, poslušali glas tvojega preroka in so v spreobrnjenju našli rešitev. Tudi mi, Gospod, medtem ko ti izročamo toliko žrtev sovraštva človeka proti človeku, kličemo tvoje odpuščanje ter prosimo za milost spreobrnjenja:

Kyrie eleison! Kyrie eleison! Kyrie eleison! (Sledila je kratka tišina.)

Gospod naš Bog, v tem mestu dva simbola pričujeta večno željo človeštva, da bi se ti približalo: mošeja Al-Nouri s svojim minaretom Al Hadba ter cerkev Naše Gospe z urnim zvonikom. Lep urni zvonik je, ki že več kot sto let spominja mimoidoče, da je življenje kratko in da je čas dragocen. Uči nas razumeti, da si nam ti zaupal svoj načrt ljubezni, miru in sprave, da bi ga skozi čas uresničili med kratkim odvijanjem našega zemeljskega življenja. Daj nam razumeti, da samo če ga brez odlašanja udejanjamo, bosta lahko zgrajena to mesto in ta dežela in bodo lahko zaradi bolečine trpeča srca ozdravljena. Pomagaj nam, da ne bomo preživeli časa v služenju svojim osebnim in skupinskim sebičnim interesom, ampak v službi tvojega načrta ljubezni. In ko bomo zašli s poti, daj, da bomo lahko prisluhnili glasovom resničnih Božjih ljudi in se pravočasno pokesali, da ne bi spet uničevali z razdejanjem in smrtjo. 
Izročamo ti tiste, katerih zemeljsko življenje je bilo prekinjeno z nasilno roko njihovih bratov, prosimo pa te tudi za tiste, ki so storili zlo svojim bratom in sestram. Naj se pokesajo ob dotiku moči tvojega usmiljenja.

Requiem aeternam dona eis, Domine, et lux perpetua luceat eis. Requiescant in pace. Amen.

\section{Prevedel p. Ivan Herceg DJ, Radio Vatikan}

Ekumenski in medverski dialog živita tudi v času koronavirusa, kar nam izpričujejo številni dogodki in dokumenti, ki smo jih objavili, in so izraz ekumenske in medverske odprtosti na svetovni ravni, kar je tudi izziv, da bi dialog udejanjali na teoretičnem in praktičnem področju tudi v Cerkvi na Slovenskem. 